\title{
Life cycle stages of the benthic palytoxin-producing dinoflagellate Ostreopsis cf. ovata
}

\section{(Dinophyceae)}

\author{
Isabel Bravo ${ }^{1 *}$, Magda Vila ${ }^{2}$, Silvia Casabianca ${ }^{3}$, Francisco Rodriguez $^{1}$, Pilar Rial ${ }^{1}$, Pilar \\ Riobó ${ }^{1}$, Antonella Penna ${ }^{3}$ \\ ${ }^{1}$ Unidad Asociada Fitoplancton Tóxico (CSIC-IEO), Instituto Español de Oceanografía (IEO). Subida \\ a Radio Faro 50, 36390 Vigo, Spain \\ ${ }^{2}$ Institut de Ciències del Mar (CSIC), Pg. Marítim de la Barceloneta 37-49, 08003 Barcelona, Spain. \\ ${ }^{3}$ Department of Biomolecular Sciences, University of Urbino, V.le Trieste 296, 61100 Pesaro, Italy
}

*E-mail address: isabel.bravo@,vi.ieo.es (I. Bravo)

\begin{abstract}
The asexual and sexual reproduction of Ostreopsis cf. ovata was studied in the field and in cultures isolated from two locations in the Mediterranean Sea. Asexual division took place in the motile stage by the sharing of theca (desmoschisis). High cell-size variability and differences in division capability were detected in the cultures. Thecal analyses and nuclear division patterns allowed characterization of the different phases of dividing cells obtained during an in situ cell-cycle sampling performed off Llavaneres beach (Northeast Spain). During the 45 -h cycle, binucleated cells accounted for $2.6 \%$ of the population. Division was initiated with the onset of dusk and reached a maximum 3-4 h before dawn. No dividing cells were detected after 09:00 AM. Sexuality occurred both in cultures and in natural populations of $O$. cf. ovata. Mating gamete pairs were the only sexual stages that could be distinguished from vegetative stages. The differences between these pairs and dividing cells are described herein. None of the individually isolated gamete pairs underwent fusion nor encystment, instead, in most of them one member of the gamete pair divided. Rather than plasmogamy, there was evidence of nuclear migration from one gamete to the other. Pellicle cysts, thin-walled cysts, and thecate cysts were also identified and studied. These cysts, embedded in abundant mucilage in a bloom-derived incubated sample, were able to germinate for as long as 6 months after their formation. Our results suggest that they constitute the overwintering population that causes recurrent blooms of $O$. cf. ovata in some areas of the Mediterranean Sea.
\end{abstract}

Key words: Ostreopsis, Mediterranean Sea, Benthic dinoflagellates, Harmful algae, Cyst, Life cycle, Reproduction. 


\section{Introduction}

Benthic dinoflagellates belonging to the tropical genus Ostreopsis are increasingly observed in temperate regions such as the Mediterranean Sea and New Zealand coast (Shears and Ross, 2009; Rhodes, 2011; Mangialajo et al., 2011). In the Mediterranean, Ostreopsis cf. ovata has been identified as a major cause of toxic blooms. Besides their economic and environmental effects, these blooms pose a threat to human health, with inhalation of their aerosols shown to be a frequent cause of respiratory illnesses in residents of the surrounding coastal areas (Ciminiello and Fattorusso, 2008; Vila et al., 2012). The adverse health effects have been ascribed to palytoxin-like compounds, which have been identified not only in blooms but also in cultures of various Ostreopsis species (Aligizaki and Nikolaidis, 2006; Riobó et al., 2006; Ciminiello et al., 2011). The increase in the occurrence of toxic bloom events has encouraged numerous investigations of the various Ostreopsis species, focusing on their taxonomy, toxinology, and phylogeography. However, very little is known about their life cycle and bloom dynamics. The most intensive blooms of Mediterranean Ostreopsis species show a remarkable seasonality, with peaks occurring during the early summer in the northwest Mediterranean Sea and in late summer-autumn in the northern Adriatic Sea. During these periods, the blooms reach their highest concentrations, although later, second blooms are also possible (Vila et al., 2001; Aligizaki and Nikolaidis, 2006; Penna et al., 2010; Totti et al., 2010; Mangialajo et al., 2011; Vila et al., 2012). By contrast, nothing is known about overwintering populations of Ostreopsis.

The seasonality of phytoplankton blooms has frequently been related to the presence of benthic cysts, which provide seed stocks for subsequent blooms (Anderson and Wall, 1978; Anderson et al, 1983; Walker 1984). Dinoflagellate cysts, mainly those produced by species responsible for red tides and other noxious blooms, have been the subject of particular interest. For example, in cyst-producing dinoflagellates, the encystment process was shown to be important in the bloom dynamics of Alexandrium species (Anderson et al., 1983; Garcés et al., 2004).

Our knowledge of the life cycle of microalgal species has advanced considerably over the last decades, but there is still much to be learned about the complexities of the life-cycle transitions carried out by phytoplankton and phytobenthos in general, and by HAB (harmful algal bloom) species in particular (Elbrächter, 2003; Figueroa et al., 2008a). Indeed, the lifecycles of benthic ciguatera-related dinoflagellates, such as those included in the genera Ostreopsis, Gambierdiscus and Prorocentrum, are poorly understood. Faust (1992) described the sexual reproduction of Coolia monotis, a species found in the same habitat as 
Gambierdiscus, Prorocentrum, and Ostreopsis. Gamete fusion in this dinoflagellate gives rise to large biflagellated planozygotes that develop into short-term pellicle cysts. The conceptual model on which dinoflagellate life-cycle studies are based mostly refers to plankton species and draws heavily on studies of benthic-pelagic coupling. However, whether benthic dinoflagellates have acquired particular life-cycle features as a function of their different ecological positions remains unclear. For example, it is unknown whether benthic dinoflagellates have a resting stage distinct from the benthic vegetative one.

The main purpose of this study was to investigate several poorly understood aspects of the asexual and sexual reproduction of $O$. cf. ovata in order to elucidate the bloom dynamics of this species. The modality through which vegetative cells divide and gametes join was characterized, such that differentiation between the two stages and among life-cycle stages was possible. A second, major objective was to examine sexual reproduction and encystment in O. cf. ovata cultures and to identify cysts of this species in the field. Putative mating gametes were individually isolated and the processes involved in their sexuality were then followed. Subsequent cytoplasmic fusion was not observed; instead, in most gamete pairs one of the cells divided. There was evidence of nuclear migration from one member of the gamete pair to the other. Moreover, cyst formation by the isolated mating gamete pairs was not observed. These findings suggested that sexual reproduction is independent of restingcyst formation, as previously reported in other dinoflagellates (Kita et al., 1993, Uchida 1996; Figueroa et al., 2006a).

\section{Material and methods}

\subsection{Isolation and maintenance of culture}

Experiments were conducted with six strains of Ostreopsis cf. ovata. They were established from seawater samples collected at Llavaneras beach (NE of Spain) and from Lopud bay (Croatia) (Fig. 1) in 2009 (Table 1). All strains were obtained by isolating single cells from epiphytic samples into the wells of tissue-culture plates (Iwaki, Japan, 6.4-mm diameter) containing $250 \mu \mathrm{L}$ of L1 medium (Guillard and Hargraves, 1993) without silica. The medium was prepared with Atlantic seawater adjusted to a salinity of 32 psu by the addition of sterile bi-distilled water. The plates were incubated at $25^{\circ} \mathrm{C}$, with a $10-\mathrm{h}: 14-\mathrm{h} \mathrm{L}: \mathrm{D}$ photoperiod and a irradiance of $180 \mu \mathrm{mol}$ photons $\mathrm{m}^{-2} \mathrm{~s}^{-1}$. Culture stocks were maintained in Erlenmeyer flasks filled with $20 \mathrm{~mL}$ of L1+K/2 (1:2 ratio) medium (Bravo et al., 2010) and were incubated under the above-described conditions. Initially, species identification was attempted based on the morphological characteristics of the cells. However, as this was 
essentially impossible, due to the large variability in cell size and shape (Penna et al., 2005), DNA analyses (described below) were performed as well .

\subsection{Molecular characterization of strains}

Single cells of Ostreopsis were picked up with a micropipette, washed in three distilled water droplets, transferred to $200-\mu \mathrm{L}$ tubes, and stored overnight at $-80^{\circ} \mathrm{C}$. The samples were then heated at $94^{\circ} \mathrm{C}$ for $1 \mathrm{~min}$ in a thermal cycler and the single cells subjected to PCR. If the DNA from single cells could not be PCR-amplified, a DNA extract prepared from five cells according to the Chelex extraction procedure (Litaker et al., 2010) was used instead. In this case, the cells were isolated, washed, and stored at $-80^{\circ} \mathrm{C}$ as above. Prior to DNA extraction, the tubes were centrifuged to pellet the cells followed by the addition of $30 \mu \mathrm{L}$ of $10 \%$ Chelex 100 (Bio-Rad, Hercules, California, USA) in $\mathrm{dH}_{2} \mathrm{O}$. The tubes were boiled at $95^{\circ} \mathrm{C}$ in an Eppendorf Mastercycler EP5345 thermocycler (Eppendorf AG, New York, USA) for 10 min, then vortexed. This step was repeated after which the samples were centrifuged at 13,000 rpm for $1 \mathrm{~min}$. The supernatants were transferred to clean $200-\mu \mathrm{L}$ tubes, avoiding carryover of the Chelex beads, and stored at $-20^{\circ} \mathrm{C}$ until they were used for PCR. The supernatants were transferred to clean $200-\mu \mathrm{L}$ tubes, avoiding carryover of the Chelex beads, and stored at $-20^{\circ} \mathrm{C}$ until they were used for PCR amplification.

The ITS1, 5.8S and ITS2 regions were amplified using the primers pairs EITS2DIR (5'GTAGGTGAACCTGC(AGC)GAAGA-3'; Guillou et al., 2002) and PERK-ITS-AS (5'GCTTACTTATATGCTTAAATTCAG-3'; Kotob et al., 1999) in $25-\mu \mathrm{L}$ reaction mixtures containing $5 \mu \mathrm{L}$ Green GoTaq ${ }^{\circledR}$ reaction buffer, 0.25 pmol of each primer, $0.2 \mathrm{mM}$ dNTPs, 0.65 units GoTaq ${ }^{\circledR}$ DNA polymerase (Promega, Madison, Wisconsin, USA), and $2 \mu \mathrm{L}$ of the Chelex extracts - or just the single-cells. DNA was amplified in an Eppendorf Mastercycler EP5345 (Eppendorf AG, New York, USA) under the following conditions: initial denaturation at $94^{\circ} \mathrm{C}$ for $2 \mathrm{~min}$, followed by 30 cycles of denaturation at $94^{\circ} \mathrm{C}$ for $1 \mathrm{~min}$, annealing at $55^{\circ} \mathrm{C}$ for $2 \mathrm{~min}$, extension at $72^{\circ} \mathrm{C}$ for $3 \mathrm{~min}$, and a final extension cycle at $72^{\circ} \mathrm{C}$ for $10 \mathrm{~min}$. A $10-\mu \mathrm{L}$ aliquot of each PCR was checked by agarose gel electrophoresis $(1 \%$ TAE, $50 \mathrm{~V}$ ) and SYBR Safe DNA gel staining (Invitrogen, California, USA).

Plasmid DNA and the PCR products were purified with ExoSAP-IT (USB Corp., Cleveland, Ohio, USA). Purified DNA was sequenced using the Big Dye Terminator v3.1 Reaction Cycle Sequencing kit (Applied Biosystems, Foster City, California, USA) and migrated in an AB 3130 sequencer (Applied Biosystems) at the CACTI sequencing facilities 
(Universidade de Vigo, Spain). The obtained sequences were deposited in the GenBank database under the accession numbers JN790686-JN790690 and JN857936.

Consensus sequences and the sequence-identity matrix for the studied strains relative to other Ostreopsis sequences available in the GenBank database (Ostreopsis cf. ovata: AJ311520, AJ318461-462, AJ320179, AJ420005, AJ491311 and AJ491312; O. ovata: AF218455-AJ218464; O. lenticularis AF076217 and O. siamensis AF076218) were obtained using Bioedit software (Hall, 1999).

\subsection{Characterization of asexual division in culture}

Vegetative cell division was studied in all strains grown in tissue-culture wells $(2 \mathrm{~mL}$ of medium) and in Erlenmeyer flasks (20 mL of medium). The cultures were performed with all strains under the conditions used for culture maintenance. Every 2-3 days, 4-ml samples were removed from the flasks and fixed in either paraformaldehyde (1\%) for nuclear staining or in Lugol for estimating cell concentration and size. The dorso-ventral (DV) and transversal (W) diameters of 30 exponentially growing cells were measured under $630 \times$ magnification using an IPplus image analyzer (Media Cybernetics, Silver Spring, MD, USA) adapted to an inverted microscope (Axiovert Zeiss 135, Germany). Measurements were performed four times during the growth curve. From tissue cultures plates, 20 cells belonging to three different size classes (DV: $25-35 \mu \mathrm{m}, 35-50 \mu \mathrm{m}$ and $>50 \mu \mathrm{m}$ ) were isolated to individual wells with $200 \mu \mathrm{L}$ of fresh medium. The cells from each well were then counted every day for the first 3 days in order to estimate the division rate. Divisions per day were calculated based on the relationship $\mathrm{Ke}=(\operatorname{Ln}(\mathrm{Ct})-\mathrm{Ln}(\mathrm{Ci})) / \mathrm{t}$ (Guillard, 1973); where $\mathrm{Ct}$ and $\mathrm{Ci}$ are the final and the initial cell concentrations, respectively, and $t=3$ days. In addition, individual cells undergoing division were isolated from tissue-culture wells for nuclear staining with Sybr Green (Molecular Probes, Eugene Oregon, USA) (Figueroa et al., 2006a) and for visualization of the thecal plates using fluorescent brightener Calcofluor (Sigma) (Fritz \& Triemer, 1985). Those cells were observed in an epifluorescence microscope (Leica DMLA, Germany) at $497 \mathrm{~nm}$ and $365 \mathrm{~nm}$, respectively, and photographed using a Canon EOS-D60 digital camera.

\subsection{Sexuality and cyst production in culture}

Intercrosses and intracrosses of the six strains listed in Table 1 were conducted in of tissue-culture well plates containing $2 \mathrm{~mL}$ of culture. Five different media were prepared based on $\mathrm{L} 1+\mathrm{K} / 2$ medium (1:2 ratio): 1) replete medium, 2) all nutrients depleted 20-fold, 3 ) 
nitrates, ammonium, and phosphates depleted 20-fold, 4) nitrates and ammonium depleted 20-fold, 5) phosphates depleted 20-fold. Exponentially growing cultures (4000-6000 cells $\left.\cdot \mathrm{mL}^{-1}\right)$ were used to inoculate each well with $1000 \mathrm{cells} \cdot \mathrm{mL}^{-1}\left(500 \mathrm{cells} \cdot \mathrm{mL}^{-1}\right.$ from each strain). The crosses were cultured under the same conditions described for culture maintenance and monitored every 2-3 days. A few putative gamete pairs were observed both in the intercrosses and intracrosses of the strains but they were left in the wells in order to obtain cysts. To provide conditions favorable to germination, the cysts were isolated onto well plates containing fresh replete medium. Altogether, attempted germinations were performed for approximately 40 cysts.

The behavior of putative gamete pairs was studied in strain VGO 1052. Six tissue-culture wells each containing a $2-\mathrm{mL}$ culture of this strain in replete $\mathrm{L} 1+\mathrm{K} / 2$ was monitored daily. Thirty six putative gamete pairs were isolated into individual wells containing either $250 \mu \mathrm{L}$ of replete medium, medium with all nutrients depleted 20 -fold or filtered seawater and monitored daily. Since gamete fusion was never observed whereas most putative gamete pairs - even though the gametes were attached - underwent division, new cells were successively removed from the wells so that only one putative gamete pair remained in each well. The latter wells were likewise monitored to observe the fusion of putative gametes. Furthermore, six new culture plates were prepared under the same conditions and used for the isolation and direct staining of 15 putative gamete pairs obtained from the cultures. Target specimens were isolated by micropipette, their nuclei stained with Sybr Green (Molecular Probes, Eugene Oregon, USA) (Figueroa et al., 2006a), and photographs taken as described above.

\subsection{In situ diel cell-cycle sampling}

Sixteen samples of macroalgae were collected at $0.5-\mathrm{m}$ depth from single station located off Llavaneres beach (Catalan coast, eastern coast of Spain) (Fig. 1). The samples were removed at 3-h intervals beginning at 12:00 PM on August 17 and ending 9:00 AM on August 19, 2010. Each sample consisted of 15-20 g of Corallina elongata and $250 \mathrm{~mL}$ of in situ seawater. The samples were shaken vigorously for $1 \mathrm{~min}$ to dislodge epiphytic organisms and then sieved, collecting the fractions $>10 \mu \mathrm{m}$ and $<140 \mu \mathrm{m}$. Three subsamples were taken from each sample: 1) for molecular characterization of the Ostreopsis species by real-time PCR (see below) since both $O$. cf. siamensis and $O$. cf. ovata had previously been recorded off Llavaneres beach (Vila et al., 2012); 2) for Lugol fixation and subsequent cell size measurements; and 3) for paraformaldehyde (final concentration of 1\%) fixation for cell 
enumeration and nuclear and thecal examinations. Up to 40 cells from each sample were measured (DV and W diameters) at 630× magnification using an IPplus image analyzer (Media Cybernetics, Silver Spring, MD, USA) adapted to an inverted microscope (Axiovert Zeiss 135, Germany). For nuclear staining, the subsample was washed in PBS pH 7 (SigmaAldrich, St. Louis, MO, USA) $(1200 \times \mathrm{g}, 10 \mathrm{~min})$. The pellet was resuspended in $2 \mathrm{~mL}$ of cold methanol (Merck, West Point, PA, USA) and stored for $12 \mathrm{~h}$ at $4^{\circ} \mathrm{C}$ to extract chlorophyll. The cells were then washed twice in PBS $(\mathrm{pH} 7)$ and the pellet was resuspended in staining solution (200:1, PBS: Sybr Green [Molecular Probes, Eugene Oregon, USA]) for at least $12 \mathrm{~h}$ before analysis. Nuclear fluorescence was observed in an epifluorescence microscope at $497 \mathrm{~nm}$. The addition of fluorescent brightener Calcofluor (Sigma) to those samples allowed, in addition, thecal observation at $365 \mathrm{~nm}$ (Fritz \& Triemer, 1985). Accordingly, vegetative, dividing cells and gamete pairs could be simultaneously distinguished by using both fluorochromes in the same sample. Up to 500 cells were enumerated in each sample; these were classified as vegetative cells , double-nucleated cells, and gamete pairs. Photographs were taken with a Canon EOS-D60 digital camera.

\subsection{Species-specific rt-PCR assay}

Approximately $5.0 \times 10^{3}$ Ostreopsis cells obtained from each in situ cell-cycle sampling were concentrated as described by Perini et al. (2011) and resuspended in $500 \mu \mathrm{L}$ of lysis buffer (Galluzzi et al., 2004). The pellets were frozen at $-80^{\circ} \mathrm{C}$ for $15 \mathrm{~min}$ and thawed at $+65^{\circ} \mathrm{C}$ for $15 \mathrm{~min}$. The freeze-thaw step was repeated three times after which the pellets were incubated at $55^{\circ} \mathrm{C}$ for $3 \mathrm{~h}$, with vortexing every $30 \mathrm{~min}$. At the end of the lysis procedure, the samples were boiled for $5 \mathrm{~min}$ to inactivate the proteinase $\mathrm{K}$ and then centrifuged at $12,000 \times \mathrm{g}$ for $1 \mathrm{~min}$ at room temperature. The supernatants, containing total genomic DNA, were processed for rt-PCR or stored at $-80^{\circ} \mathrm{C}$ until needed. Real-time PCR amplifications were carried out using species-specific primers for O. cf. ovata (Perini et al. 2011) and O. cf. siamensis (Penna et al., 2007). The rt-PCR assays were performed in a final volume of $25 \mu \mathrm{L}$ using the Hot-Rescue Real-Time PCR Kit-SG (Diatheva, Fano, Italy) containing $1 \times$ SYBR Green dye, primers at a final concentration of $300 \mathrm{nM}, 0.5 \mathrm{U}$ of HotRescue Plus DNA polymerase, and $2 \mu$ of crude extracts diluted 1:10 and 1:100. All reactions were carried out using a Step-one Real-time PCR system (Applied Biosystems, Foster City, CA, USA) and the following thermal cycling conditions: $10 \mathrm{~min}$ at $95^{\circ} \mathrm{C}$, followed by 40 cycles at $95^{\circ} \mathrm{C}$ for $15 \mathrm{~s}$ and $60^{\circ} \mathrm{C}$ for $1 \mathrm{~min}$. A dissociation protocol was 
carried out after the PCR amplification to exclude the presence of primer dimers and nonspecific products.

\subsection{Cyst induction from field-sample incubations and cyst germination}

Macroalgae samples were obtained on July 29, 2009 and August 19, 2010 during blooms of O. cf. ovata at Llavaneres beach (Fig 1). Epiphytic organisms were removed as described for the diel cell-cycle experiment. The sample was divided into four subsamples, each of which was incubated in the laboratory in $2 \mathrm{~L}$ of filtered seawater at $20^{\circ} \mathrm{C}$ and a $12-\mathrm{h}: 12-\mathrm{h}$ L:D photoperiod. Treatment of the four subsamples differed as follows: 1) F/2 medium, with aeration, 2) F/2 medium, without aeration, 3) without nutrient enrichment, with aeration, and 4) without nutrient enrichment and without aeration. One month later, the subsamples were passed through a $140-\mu \mathrm{m}$ and $10-\mu \mathrm{m}$ sieves and the fraction collected between these sizes was observed using a light microscope and epifluorescence at $497 \mathrm{~nm}$ (Leica DMLA, Germany). Ostreopsis cells were photographed using a Canon EOS-D60 digital camera. Cyst germination and viability were studied in samples stored at $15^{\circ} \mathrm{C}$ in darkness. Twenty cysts were isolated every 2 months and transferred to the wells of tissue-culture plates filled with $\mathrm{L} 1+\mathrm{K} / 2$ medium (1:2 ratio) medium. The cultures were checked every 1-3 days until germination, for at least 15 days. Excystment was defined as the complete emergence of the protoplasts from the cysts (Figueroa et al., 2006a).

\subsection{Resting cysts in the sediments and on the macroalgae}

During 2009 and 2010, the protocol described in diel cell-cycle sampling was used to collect up to five epiphytic samples every month from the same station off Llavaneres beach (0.5 m depth) (Fig. 1). The epiphytic organisms were dislodged by shaking and sieving (10$140 \mu \mathrm{m})$ and the samples then examined by light microscopy, searching for Ostreopsis cysts. In addition, a survey was performed on September 30, 2009, when the bloom had declined, at the same location but at greater depths. Thus, a total of 50 samples of different macroalgae or Posidonia oceanica (10-20 g) or sediment (15-25 $\left.\mathrm{cm}^{3}\right)$ were obtained at depths of $2 \mathrm{~m}$ (macroalgae), $4 \mathrm{~m}$ (sand), $6 \mathrm{~m}$ (macroalgae), $8 \mathrm{~m}$ (mixture of macroalgae and sand) and $9 \mathrm{~m}$ (Posidonia oceanica). Macroalgal and seagrass samples were processed as described for the in situ cell-cycle samples. Sandy sediments were gently sonicated and then sieved, collecting the fractions $>10 \mu \mathrm{m}$ and $<100 \mu \mathrm{m}$. Fine-grained sediments were separated using a sodium polytungstate density-gradient procedure (Bravo et al., 2006). The final samples were observed with a light microscope (Leica DMLA, Germany) and photographed with a Canon 
EOS-D60 digital camera. Cysts putatively attributed to Ostereopsis cf. ovata $(n=150)$ were isolated into tissue-culture plates filled with $\mathrm{L} 1 / 20$ medium and incubated at $24^{\circ} \mathrm{C}$ under a photoperiod of 12-h:12-h L:D cycle, monitoring the cultures every 1-3 days. The resulting vegetative cells could then be assessed for the purpose of species confirmation.

\section{Results}

3.1 Molecular characterization of the cultured strains and analysis of the variability in cell size

DNA sequencing of partial ITS1, 5.8SrDNA, and ITS2 obtained from all Ostreopsis cultures (Table 1) yielded almost identical sequences for these regions. Only a few polymorphisms in ITS2 were found, in clones VGO1068 and VGO1070 (2 and 4 bases, respectively). The Ostreopsis strains used in this study were identified as O. cf. ovata based on their high similarity $(>0.99)$ with the consensus sequences of $O$. cf. ovata available in the GenBank database. Significantly lower similarities were determined in a comparison of our Ostreopsis strains with the O. ovata (0.81), O. siamensis (0.86), and O. lenticularis (0.84) sequences from GenBank.

Cell size was highly variable in the cultures, with the DV diameter ranging from 27 to 85 $\mu \mathrm{m}$ and the $\mathrm{W}$ diameter from 17 to $51 \mu \mathrm{m}$. The total population average was $47 \mu \mathrm{m} \mathrm{DV}$ $(\mathrm{std}=9, \mathrm{n}=719)$ and $35 \mu \mathrm{m} \mathrm{W}(\mathrm{std}=8, \mathrm{n}=719)$. Median, interquartile range, outliers, and extreme cases of the measurements from all strains are shown in the box-plots of Fig. 2A, B. Significant differences $(\mathrm{p}<0.001)$ were determined between strains VGO1067, VGO1068, and the other strains (Fig 2A, B). In addition, division capability differed between cells of different sizes. Thus, small cells (25-35 $\mu \mathrm{m}$ DV) were unable to divide within 2 days and underwent $0.1 \pm 0.1$ divisions per day after 3 days. By contrast, medium-size $(35-50 \mu \mathrm{m} \mathrm{DV})$ and large ( $>50 \mu \mathrm{m}$ DV) cells divided from the first day, reaching $0.4 \pm 0.2$ and $1 \pm 0.2$ divisions per day for the 3 days, respectively.

\subsection{Asexual division in the cultures}

Cytokinesis was monitored during the first few days of culture, when cells undergoing vegetative division were frequently observed. Cells divided by desmoschisis in the sagittal plane, with each daughter cell inheriting part of the parental thecal plates. The nuclei of the dividing cells were positioned centrally (Fig 3A). During cell division, the nuclear content was replicated first, yielding double-nucleated cells. Next, a visible ventral to dorsal partition wall developed while the original parental theca was maintained (Figs. 3A-C). When the 
cells separated, the thecal plates split and were distributed between the two daughter cells. These recently divided cells, still with incomplete thecae, separated rapidly. Examination of their theca revealed that plate separation occurred along predetermined sutures. The fission pattern for the epithecal plates was: Po, all apicals (1'-4') and precingulars 1" and 2" going to one daughter cell and precingulars 3-6" to the other (Fig. 3D). Based on these characteristics, the dividing cells in the field samples could be clearly identified.

\subsection{In situ cell cycle}

A total of 16 epiphytic samples were taken at different times during a 45-h sampling, carried out during the most intensive period of the August 2010 bloom. The samples were analyzed by qualitative rt-PCR for the purpose of taxonomic classification of Ostreopsis species. Only $O$. cf. ovata was identified, based on exclusion of the co-occurrence of $O$. cf. siamensis. O. cf. ovata was the dominant taxon in all samples, representing $>90 \%$ of the total microphytobenthos. The average microalgal cell concentration during sampling was 6.2 $\times 10^{5}$ cells g ${ }^{-1}$ (fresh weight of macroalgae) $\left(\mathrm{std}=2.6 \times 10^{5}, \mathrm{n}=16\right)$ and $2.9 \times 10^{6}$ cells g $^{-1}$ (dry weight of macroalgae) $\left(\mathrm{std}=1.210^{6}, \mathrm{n}=16\right)$. Cell sizes were highly variable, ranging from 24 to $87 \mu \mathrm{m} \mathrm{DV}$ and 13 to $53 \mu \mathrm{m} \mathrm{W}$, with a mean DV of $56 \mu \mathrm{m}(\mathrm{std}=9, \mathrm{n}=622)$ and a mean W of $33 \mu \mathrm{m}(\mathrm{std}=6, \mathrm{n}=620)$. No significant differences were found between samples obtained at different times, although some differences between the confidence intervals of the cell sizes were observed (Fig. 2C, D).

Five stages were distinguished during cell-cycle analysis: 1) dorsal nucleated cells, the most abundant form (Fig. 3E); 2) centrally nucleated cells, representing a stage preceding karyokinesis (Fig. 3F); 3) cells undergoing karyokinesis (Fig. 3G); 4) double-nucleated cells undergoing different phases of cytokinesis while retaining the theca (Fig. 3H-J); 5) recently divided cells still displaying a lateral nucleus and incomplete thecal plates (Fig. 3K, L).

Double-nucleated cells were counted, thereby distinguishing two asexual binary-fission cycles during the sampling period, i.e., one every 24 -h cycle. The pattern of cell division is shown in Fig. 4. Although double-nucleated cells comprised a maximum of $2.5 \%$ of the sample, the total number of dividing cells per 24-h cycle may have been higher depending on the duration of the binucleated phase during the division process. Division started at 09:00 PM, coinciding with the onset of dusk, and reached a maximum at 3:00 AM, 3 h before dawn. No double-nucleated cells were observed after 09:00 AM.

\subsection{Sexual stages in culture}


Putative gamete pairs were rarely observed either in the intercrosses or the intracrosses of the different strains. These putative gamete pairs were clearly distinguishable from dividing cells, as vegetative division always occurred in the sagittal plane (Fig. 3C) such that the daughter cells were joined laterally until they detached, which occurred very quickly. By contrast, putative gametes were mostly joined by epitheca (Fig 3M), with the point of attachment positioned centrally to slightly laterally or ventrally. The rapid separation of recently dividing cells along with the differences in their positions allowed these cells to be morphologically distinguished from putative gamete pairs. So, dividing cells had only one theca, unlike the two thecae - from the two gametes - of the gamete pair (compare Figs. 3A$\mathrm{C}$ and Figs. 3M-P). This difference was maintained regardless of the extent of gamete-pair attachment and despite the other, arbitrary attachments that were occasionally observed (Fig. $3 \mathrm{~N}$ and $\mathrm{O})$.

Most of the putative gamete pairs underwent division - even though the gametes were attached - when the pairs were isolated into individual wells irrespective of the medium used and even when they were maintained in the same tissue-culture well in which they had formed. Division occurred in only one of the cells of the pair and followed the same pattern as described in asexual fission (Fig. 3Q). There were no signs of plasmogamy.

The stained nuclei of the isolated putative gamete pairs showed the following features:

1) A few pairs seemed to be in the initial process of mating since the contact between cells was apparently limited to the thecae (Fig. 3P). The nucleus from each putative gamete from these pairs was always visible.

2) In some pairs, there was greater surface contact between cells in addition to indications of nuclear transfer from one gamete to the other. Figure 3R shows a gamete with its nucleus positioned laterally, very close to the cell wall. In Figure 3S, the transfer of a nucleus from one gamete to the other is seen. Finally, as shown in Figure 3T, few pairs presented only one visible nucleus, located in just one of the cells of the pair.

Although, the gametes from the pairs were as variable in size as the vegetative cells, they were mostly isogamous (for example, all the gametes shown in Figure 3), with very few anisogamous pairs detected.

\subsection{Putative gamete pairs during an "in situ” diel cell cycle at Llavaneres beach}

Putative gamete pairs were detected during the in situ cell cycle. These paired cells showed the characteristics mentioned above in the cultures. Cell counts showed that they comprised $<1 \%$ of the total cells of $O$. cf. ovata (Fig. 4). Some gamete pairs appeared to be 
in a more advanced state of fusion (Figs. 3U, V) than others, in which apparently there was only surface contact between the gametes (Figs. 3W, X).

\subsection{Cysts in culture}

Cysts never formed in cultures derived from isolated fusing gamete pairs. Intracrosses or intercrosses of the strains only rarely yielded round thin-walled cells that could be considered as cysts (Fig. 5A). Moreover, few cysts similar to those shown in Figure 5A were obtained in culture wells derived from the various experiments performed during the present study. Among all cysts isolated into fresh medium, only one germinated (Fig. 5B). Since the cyst germinated only 3 days after its formation, it was considered to be a non-dormant cyst. The remaining isolated cysts degraded within a few days.

\subsection{Cysts in the field samples}

Thin-walled cysts varying in shape, from round to elongated, were sporadically observed in epiphytic samples collected at Llavaneres beach at $0.5 \mathrm{~m}$ depth, both from bloom and nobloom seasons (Figs. 5C-D). Non-flagellated athecate cells with the characteristic Ostreopsis shape were also observed in the samples (Fig. 5E). These were considered to be pellicle cysts that had formed from ecdysis; however, it was not possible to determine whether their formation was prior to or during sample manipulation. Both thin-walled cysts and pellicle cysts germinated within $24 \mathrm{~h}$ after their isolation into fresh replete medium, yielding $O$. cf ovata cells. The cytoplasmic content ranged from densely to sparsely granulated.

Cysts of Ostreopsis were not identified in 50 substrate samples obtained from greater depths in September 2009. This result was based on the examination of $>300$ putative dinoflagellate resting cysts and 150 isolations for the purpose of germination and further identification. Only a few of the 300 cysts detected in the field samples resembled those of Ostreopsis cf. ovata cysts (Fig. 5F), but their species attribution could not be tested because they failed to germinate.

Furthermore, cysts completely embedded in mucus were produced from incubations of the bloom samples obtained in July 2009 but not from the August 2010 sampling. In the former case, cysts were produced both in nutrient-enriched samples incubated with aeration and in the absence of nutrients and aeration. Their shape was mostly typical of Ostreopsis cells (Fig. 5G) but thin-walled and pellicle cysts similar to those described for the shallower samples (Figs. 5C-E) were also observed. The cytoplasm was mostly thickly granulated. In some cells, red spots were observed at bright-field microscopy. Under epifluorescence, the 
spots exhibited the red fluorescence characteristic of chlorophyll (Fig. 5H), on the contrary autofluorescence was not seen in the thick grains. Every two-months, these cysts were isolated into fresh replete medium, which resulted in 100\% germination 2 months after their production, $30 \%$ after 4 months, and $80 \%$ after 6 months.

\section{Discussion}

This report provides the first description of the various stages, asexual as well as sexual, of one species of the genus Ostreopsis. The identification and description of these stages are fundamental to life-cycle studies and to our understanding of the ecology of this species. The resting cyst originating from sexual reproduction is considered to be essential to the seeding strategy of seasonal dinoflagellates such as those belonging to the genus Alexandrium (Anderson, 1998). Given the seasonality and recurrence of O. cf. ovata blooms in the Mediterranean Sea (Vila et al., 2001; Penna et al., 2005; Aligizaki and Nikolaidis, 2006; Totti et al., 2010; Mangialajo et al., 2011; Vila et al., 2012), it is important to determine the life history of this species, particularly, the existence of a resting stage. Our results suggest that sexuality in O. cf. ovata is unlikely to be related to the formation of dormant resting cysts. Moreover, our work describes the formation of pellicle cysts, thin-walled cysts and thecate cysts from natural populations of this species. Those cysts were able to germinate for up to 6 months following their formation. Their significance and that of the other life stages observed in this study are discussed below.

\subsection{Asexual behavior.}

The pattern of vegetative cell division described herein is consistent with that reported by Besada et al. (1982). Careful observation of the thecal and nuclear division patterns allowed the dividing cells to be characterized and subsequently distinguished from putative sexual mating stages (see Sexual stages in culture in Results). This was possible because the dividing cells, as shown in Figure 3A, were readily identified. By using inverted microscopy to follow some of these cells in tissue culture plates, we determined that the time needed from that division stage until complete separation was less than one hour and that once the newly formed cells had initiated separation it was completed within just a few minutes. Therefore, dividing cell pairs shown in Fig. 3A-C were clearly distinguishable from the gamete pairs shown in Figures 3M, N, V, X.

One remarkable feature observed in growing cultures was the highly variable cell sizes and daily division rates. The largest cells $(>50 \mu \mathrm{m}$ DV) were characterized by high rates of 
daily divisions, which suggested that when isolated they were already in the process of dividing. None of the smallest cells $(<35 \mu \mathrm{m}$ DV) divided during the first 3 days in culture and only $28 \%$ had divided by the third day. Although data regarding the composition of the different size classes were not obtained along the growth curve, in the initial phases in the culture plates cells $<35 \mu \mathrm{m}$ DV were never observed, but they did appear after several successive transfers to new medium. The presence of small cells morphologically similar to smaller vegetative cells is common in dinoflagellate life cycles and has been ascribed to the rapid asexual divisions that promote rejuvenation of the cell population (Partensky and Vaulot, 1989; Silva, 1989). In Alexandrium taylori and Alexandrium peruvianum, small cells are associated with the post-meiotic germination of a pellicle hypnocyst (Figueroa et al. 2006b, 2008b). Many authors have noted that small dinoflagellate cells behave either as vegetative cells or as gametes (Sckoczylas, 1958; Cao Vien, 1967; Partensky and Vaulot, 1989; Pfiester, 1989). Our observations, both in cultures and in natural samples of $O$. cf. ovata, of gametes of all sizes add to the controversy regarding the importance of cell size in gamete function in dinoflagellates.

\subsection{Division patterns in natural populations of Ostreopsis cf. ovata}

The presence of more than one morphologically recognizable phase within the cell division patterns of $O$. cf. ovata may facilitate estimation of the in situ division rates in natural populations of this species. Several approaches to in situ measurements of speciesspecific growth rates based on cell-cycle analysis have been described (Smith and Dendy, 1962; McDuff and Chisholm, 1982; Carpenter and Chang, 1988) and they involve quantifying the fraction of the population undergoing a cell-cycle terminal event. This in turn requires calculation of the event's duration, which may be estimated if the size of the fraction of cells undergoing other consecutive terminal event is known (Chang and Carpenter, 1991). The frequencies of double-nucleated cells, indicative of ongoing cytokinesis, and the number of recently divided cells were shown to define the fraction of cells in terminal events in populations of Dinophysis spp. (Garcés et al., 1997). As demonstrated in the present work, the identification of several phases from populations of $O$. cf. ovata is possible; however, during our experiments, only double-nucleated cells were quantified since cells in the other phases were detected in numbers too low to be statistically significant. This was likely due to both the extreme rapidity of these phases and the low resolution of the sampling. Both a more intensive field sampling and improvements in the size of the counted sample are needed to overcome this problem, in addition to providing an accurate estimate of the fraction of 
mitotic cells. Moreover, the interval in which a cohort of cells passes from the initial mitotic phase (Fig. 3E) to the terminal mitotic phase (Fig. 3J-L) would likely serve as an estimate of the duration of mitosis.

\subsection{Sexual behaviour.}

The ability to differentiate asexual from sexual stages is crucial in studies of the reproductive processes of dinoflagellates. In these organisms, the study of sexual cycles is dependent on the ability to distinguish planozygotes and fusing gamete pairs from vegetative and dividing cells. In the present work, the recognition of dividing cells based on their thecal and nuclear features suggested that the remaining cell pairs detected in the cultures were mating gamete pairs. This allowed subsequent efforts to focus on the conjugation and fusion of these putative gametes, from which planozygotes should be developed. However, none of the individually isolated putative gamete pairs underwent fusion; instead, most of them divided. Migration of the nucleus from one gamete to the other confirmed that the putative gamete pairs were indeed mating gametes and, therefore, that one of the resulting cells was a zygote able to undergo division, as has been described for many dinoflagellate species (Uchida, 1996; Figueroa and Bravo 2005a,b; Figueroa et al 2006a,b). Our results further suggest that gamete conjugation of $O$. cf. ovata can be carried out through karyogamy, without requiring cytoplasmic fusion. The temporary conjugation of gametes through nuclear transmission from one gamete to the other one, rather than plasmogamy, as well as the posterior degeneration of the gamete lacking the nucleus was reported in Prorocentrum micans (Bhaud and Soyer-Gobillard, 1988). Nuclear migration from one gamete to the other prior to fusion has also been described in G. catenatum (Figueroa et al., 2006b) although in this species plasmogamy was the most common process during gamete conjugation.

Alternatively, it can not be excluded that some of the gamete pairs were divided before nuclear migration occurred. This was suggested by the fact that: (i) these pairs showed only theca to theca contact and (ii) division followed the same pattern as that of vegetative cells. Dividing gamete pairs have been amply observed in cultures of $G$. catenatum, in which the cells divided before the end of syngamy (Figueroa et al., 2006b). The authors of that study reported that a sudden change in the nutritional content of the culture medium corresponded to the division of the gamete pairs before cytoplasmic fusion was completed. This was attributed to the versatility of the sexual stages of G. catenatum, i.e., resting-cyst formation can be shortened or even bypassed in response to external conditions. Furthermore, in life- 
cycle studies of A. taylori, in which some of the isolated gamete pairs were observed to separate, the gametes divided and formed the basis of a new culture (Figueroa et al., 2006a).

In the present work, a low number of putative mating gamete pairs were detected in natural populations and in cultures. This fact along with the well-known difficulties of differentiating sexual stages from vegetative cells limited further investigations into the sexuality of $O$. cf. ovata. Further experiments are needed to clarify whether the mode of gametic conjugation involves plasmogamy. In fact, in a very few cases, putative gamete pairs established broader surface contact, perhaps indicative of gamete fusion. Regardless, the confirmed ability of gamete pairs isolated from $O$. cf. ovata cultures to undergo division suggested a high degree of flexibility between the sexual and asexual processes of this species, as also reported, for instance, for G. catenatum (Figueroa et al., 2008a).

Our data showed that sexuality occurs both in cultures and in natural populations of $O$. cf. ovata. However, much remains to be learned before a complete picture of all the processes involved in sexuality is obtained. For example, a method for planozygote identification is needed. In dinoflagellates, the presence of two flagella is the most common microscopy feature used to distinguish planozygotes from vegetative cells, as the two stages are otherwise morphologically very similar. Yet our attempts to recognize biflagellate cells were unsuccessful due to the extremely short longitudinal flagella of this species, as shown by electron microscopy (data not published), and to the fact that in the absence of plasmogamy a gamete-like planozygote with a single flagellum originated, as expected.

\subsection{Cysts and seeding strategy.}

The yearly recurrence of $O$. cf. ovata blooms in summer and the nearly complete disappearance of these cells in winter (Vila et al., 2012) suggests the existence of a seeding strategy for bloom initiation. Whereas benthic seed banks are widely accepted as the source of the recurrent blooms of some species of phytoplankton species, this function has yet to be confirmed in benthic populations. In accordance with their habitat, the evolution of benthic species is thought to have included particular traits that allow them to survive in the benthos. Nonetheless, resting cysts have not been reported for the well-known ciguatera-related species or for other dinoflagellates occupying the same habitat, such as Coolia monotis, a species morphologically similar to Ostreopsis in which sexual reproduction is known to give rise only to short-term pellicle cysts (Faust, 1992).

Several of the cells followed in this study were likely to have been cysts. The various forms included: 1) non-motile vegetative-like cells, also called thecate cysts; 2) ecdysal cells 
with the same shape as vegetative cells, known as pellicle cysts; and 3) round to elongated thin-walled cysts. All of these forms were detected inside threads of mucous and were viable for more than 6 months after their formation, consistent with the suggestion that those cysts could constitute an overwintering population responsible for bloom recurrence. Interestingly, only the mucilage-covered cysts survived in the samples, suggesting that the mucilaginous matrix acts as a protective coat, although it has also been suggested to function as a trap (Barone, 2007). The extracellular polysaccharides produced by and associated with algal trichomes were similarly proposed to serve a defensive function against predation in some cyanobacteria (Dodds et al., 1995, Pajdak-Stós et al., 2001). Allelopatic components have been reported to be produced as a chemical defense strategy by some dinoflagellate species (Pohnert 2004). Clearly, as with many other aspects of Ostreopsis, much remains to be learned about the role of the mucous coating in the proliferation and survival of this species.

\section{Acknowledgements}

We thank Helena Hojas for her help in the culture and subsequent measurements of Ostreopsis, Amelia Villamarín for providing technical support, and Santiago Fraga for his assistance in elucidate the pattern of dividing cells. Mercedes Massó aboard the sailboat "Rael V" is gratefully acknowledged for the supply of samples from Croatia, and Cecilia Battochi for her assistance in overnight sampling at Llavaneres beach. We are also indebted to the Aceña family, from the Restaurant Pins Mar (Sant Andreu de Llavaneres), for kindly offering us the use of their facilities. This work was supported by the Spanish national project EBITOX (CTQ2008-06754-C04-04). We also thank the CCVIEO-Microalgae Culture Collection of Instituto Español de Oceanografía for providing culture strains.

\section{References}

Aligizaki, K., Nikolaidis, G., 2006. The presence of the potentially toxic genera Ostreopsis and Coolia (Dinophyceae) in the North Aegean Sea, Greece. Harmful Algae 5, 717-730.

Anderson, D.M., Wall, D., 1978. Potential importance of benthic cysts of Gonyaulax tamarensis and G. excavata in initiating toxic dinoflagellate blooms. J. Phycol. 14, 224234.

Anderson, D.M., Chisholm, S., Watras, C., 1983. Importance of life cycle events in the population dynamics of Gonyaulax tamarensis. Mar. Biol. 76,179-189.

Anderson, D.M., 1998. Physiology and Bloom Dynamics of Toxic Alexandrium Species, with Emphasis on Life Cycle Transitions. In: Anderson et al. (Eds.), Physiological 
Ecology of Harmful Algal Blooms, NATO ASI Series, Springer-Verlag Berlin Heidelberg, pp. 29-48.

Barone, R., 2007. Behavioural trait of Ostreopsis ovata (Dinophyceae) in Mediterranean rock pools: the spider's strategy. Harmful Algal News 33, 1-3.

Besada, E.G., Loeblich, L.A., Loeblich III, A.R., 1982. Observations on tropical, benthic dinoflagellates form ciguatera-endemic areas: Coolia, Gambierdiscus, and Ostreopsis. Bull. Mar. Sci. 32, 723-735.

Bhaud, Y., Soyer-Gobillard, M.O., Salmon, J.M., 1988. Transmission of gametic nuclei through a fertilization tube during mating in a primitive dinoflagellate, Prorocentrum micans Ehr. J. Cell. Sci. 89, 197-206.

Bravo, I., Garcés, E., Diogéne, J, Fraga, S., Sampedro, N., Figueroa, R.I., 2006. Resting cysts of the toxigenic dinoflagellate genus Alexandrium in recent sediments from the Western Mediterranean coast, including the first description of cysts of $A$. kutnerae and A. peruvianum. Eur. J. Phycol. 41, 293 -302.

Bravo, I., Vila, M., Magadán, S., Rial, P., Rodriguez, F., Fraga, S., Franco, J.M., Riobó, P., Sala, M.M., 2010. Studies on cultures of Ostreopsis cf ovata: life cycle observations. In: Proceeding of the 14th International Conference on Harmful Algae. Hersonissos, Crete (Greece) 1-5 Novembre 2010.

Cao Vien, M., 1967. Sur 1'existence de phénomènes sexualles chez un Péridinien libre, 1'Amphidinium carteri Hulburt. Compte Rendu de 1'Académie des Sciences, Paris 246, 1006-1008.

Carpenter, E.J., Chang, J., 1988. Species-specific phytoplankton growth rates via diel DNA synthesis cycles. I. Concept of the method. Mar. Ecol. Prog. Ser. 43, 105-111.

Chang, J., Carpenter, E.J., 1991. Species-specific phytoplankton growth rates via diel DNA synthesis cycles. V. Application to natural populations in Long Island Sound. Mar. Ecol. Prog. Ser. 78, 115-122.

Ciminiello, P., Dell'Aversano, C., Iacovo, E.D., Fattorusso, E., Forino, M., Tartaglione, L., 2011. LC-MS of palytoxin and its analogues: State of the art and future perspectives. Toxicon 57, 376-389.

Ciminiello, P., Fattorusso, E., 2008. Chemistry, Metabolism and Chemical Analysis. In: Botana, L.M. (Ed.), Seafood and Freshwater Toxins. Pharmacology, Physiology and Detection, Second edition, CRC Press, pp. 287-314.

Dodds, W.K., Gudder, D.A., Mollenhauer, D., 1995. The ecology of Nostoc. J. Phycol. 31, 218. 
Elbrächter, M., 2003. Dinophyte reproduction: progress and conflicts. J. Phycol. 39, 629-632.

Faust, M.A., 1992. Observations on the morphology and sexual reproduction of Coolia monotis (Dinophyceae). J. Phycol. 28, 94-104.

Figueroa, R. I., Bravo, I., 2005a. A study of the sexual reproduction and determination of mating type of Gymnodinium nolleri (Dinophyceae) in culture. J. Phycol. 41, 74-83.

Figueroa, R. I., Bravo, I., 2005b. Sexual reproduction and two different encystment strategies of Lingulodinium polyedrum (Dinophyceae) in culture. J. Phycol. 41, 370-379.

Figueroa, R. I., Bravo, I., Garcés, E., 2006a.The multiple routes of sexuality in Alexandrium taylori (Dinophyceae) in culture. J. Phycol. 42, 1028-1039.

Figueroa, R. I., Bravo, I., Garcés, E., Ramilo, I., 2006b. Nuclear features and effect of nutrients on Gymnodinium catenatum (Dinophyceae) sexual stages. J. Phycol. 42, 67-77.

Figueroa, R.I., Bravo, I., Ramilo, I., Pazos, Y., Angeles, M., 2008a. New life-cycle stages of Gymnodinium catenatum (dinophyceae): laboratory and field observations. Aquat. Microb. Ecol. 52, 13-23.

Figueroa, R. I., Bravo, I., Garcés E., 2008b. The significance of sexual versus asexual cyst formation in the life cycle of the noxious dinoflagellate Alexandrium peruvianum. Harmful Algae 7, 653-663.

Fritz, L., Triemer, R.E., 1985. A Rapid Simple Technique Utilizing Calcofluor White M2r for the Visualization of Dinoflagellate Thecal Plates. J. Phycol. 21, 662-664.

Galluzzi, L., Penna, A., Bertozzini, E., Vila, M., E. Garces, Magnani, M., 2004.

Development of a real-time PCR assay for rapid detection and quantification of Alexandrium minutum (a dinoflagellate). Appl. Environ. Microbiol. 70,1199-1206.

Garcés, E., Bravo, I., Vila, M., Figueroa, R. I., Masó, M. and Sampedro, N., 2004. Relationship between vegetative cells and cyst production during Alexandrium minutum bloom in Arenys de Mar harbour (NW Mediterranean).2004. J. Plankton Res. 26, 637645.

Garcés, E., Delgado, M., Camp, J., 1997. Phased cell division in natural population of Dinophysis sacculus and the in situ measurement of potencial growth rate. J. Plankton Res. 19, 2067-2077.

Guillard, R. R. L., 1973. Division rates. In: Stein J. R. (Ed.), Handbook of Phycological Methods Culture Methods and Growth Measurements, Cambridge University Press, Cambridge, pp. 289-311.

Guillard, R.R.L., Hargraves, P.E., 1993. Stichochrysis inmobilis is a diatom, not a chrysophyte. Phycologia 32, 234-236. 
Guillou, L., Nézan, E., Cueff, V., Erard-Le Denn, E., Cambon-Bonavita, M.-A., Gentien, P., Barbier, G., 2002. Genetic Diversity and Molecular Detection of three toxic dinoflagellate genera (Alexandrium, Dinophysis, and Karenia) from French coasts. Protist 153, 223-238.

Hall, T., 1999. BioEdit: a user-friendly biological sequence alignment editor and analysis program for Windows 95/98/NT. Nucl. Acid S. 41, 95-98.

Kita, T., Fukuyo, Y., Tokuda, H., Hirano, R., 1993. Sexual reproduction of Alexandrium hiranoi (Dinophyceae). Bull. Plankton Soc. Japan 39, 79-85.

Kotob, S. I., McLaughlin, S.M., Van Berkum, P., Faisal, M., 1999. Discrimination between two Perkinsus spp. isolated from the softshell clam, Mya arenaria, by sequence analysis of two internal transcribed spacer regions and the 5.8S ribosomal RNA gene. Parasitology 199, 363-368.

Litaker, R.W., Vandersea, M.W., Faust, M.A., Kibler, S.R., Nau, A.W., Holland, W.C., Chinain, M., Holmes, M.J., Tester, P.A., 2010. Global distribution of ciguatera causing dinoflagellates in the genus Gambierdiscus. Toxicon 56, 711-730.

Mangialajo, L., Ganzin, N., Accoroni, S., Asnaghi, V., Blanfuné, A., Cabrini, M., CattaneoVietti, R., Chavanon, F., Chiantore, M., Cohu, S., Costa, E., Fornasaro, D., Grossel, H., Marco-Miralles, F., Masó, M., Reñé, A., Rossi, A.M., Sala, M.M., Thibaut, T., Totti, C., Vila, M., Lemée, R., 2011. Trends in Ostreopsis proliferation along the Northern Mediterranean coasts. Toxicon 57, 408-420.

McDuff, R.E., Chisholm, S.W., 1982. The calculation of in situ growth rates of phytoplankton populations from fractions of cells undergoing mitosis: A clarification. Limnol. Oceanogr. 27, 783-788.

Pajdak-Stós, A., Fialkowska, E., Fyda, J., 2001. Phormidium autumnale (Cyanobacteria) defense against three ciliate grazer species. Aquat. Microb. Ecol. 23, 237-244.

Partensky, F., Vaulot, D., 1989. Cell size differentiation in the bloom-forming Gymnodinium cf. nagasakiense. J. Phycol. 25, 741-750.

Penna, A., Vila, M., Fraga, S., Giacobbe, M.G., Andreoni, F., Riobó, P., Vernesi, C., 2005. Characterization of Ostreopsis and Coolia (Dinophyceae) isolates in the Western Mediterranean Sea based on morphology, toxicity and internal transcribed spacer 5.8S rDNA sequences. J. Phycol. 41, 212-225.

Penna, A., Bertozzini, E., Battocchi, C., Giacobbe, M. G. , Galluzzi, L., Garces, E. , Vila, M., Lugliè, A., Magnani, M., 2007. Monitoring of HAB species in the Mediterranean Sea through molecular techniques. J. Plankton Res. 29, 19-38. 
Penna, A., Fraga, S., Battocchi, C., Casabianca, S., Giacobbe, M.G., Riobó, P., Vernesi, C., 2010. A phylogeographical study of the toxic benthic dinoflagellate genus Ostreopsis Schmidt. J. Biogeogr. 37, 830-841.

Perini, F., Casabianca, A., Battocchi, C., Accoroni, S., Totti, C., Penna, A., 2011. New Approach Using the Real-Time PCR Method for Estimation of the Toxic Marine Dinoflagellate Ostreopsis cf. ovata in Marine Environment. PLoS ONE 6,e17699. Pfiester, L.A., 1989. Dinoflagellate sexuality. Int. Rev.Citol. 114, 249-272.

Pohnert, G., 2004. Chemical defense strategies of marine organisms. Topics in Current Chemistry 239, 179-219.

Rhodes, L., 2011. World-wide occurrence of the toxic dinoflagellate genus Ostreopsis Schmidt. Toxicon 57, 400-407.

Riobó, P., Paz, B., Franco, J.M., 2006. Analysis of palytoxin-like in Ostreopsis cultures by liquid chromatography with precolumn derivatization and fluorescence detection. Anal. Chim. Acta 566, 217-233.

Skoczylas, O., 1958. Über die Mitosis von Ceratium cornutum (Her.) Claparède et Lachmann und einigen Peridineen. Archiv für Protistenkunde 103, 193-228.

Shears, N.T., Ross, P.M., 2009. Blooms of benthic dinoflagellates of the genus Ostreopsis; an increasing and ecologically important phenomenon on temperate reefs in New Zealand and worldwide. Harmful Algae 8, 916-925.

Silva, E.S., 1989. Different interpretations of the small forms in the cell cycle of dinoflagellates. In: Ford, L.N. (Ed.), Proceedings of the $4^{\text {th }}$ Conference on modern and Fossil Dinoflagellates, Woods Hole, MA, p. 93.

Smith, C.L., Dendy, P.P., 1962. Relation between mitotic index, duration of mitosis, generation time and fraction of dividing cells in a cell population. Nature 4815, 555-556

Totti, C., Accoroni, S., Cerino, F., Cucchiari, E., Romagnoli, T., 2010. Ostreopsis ovata bloom along the Conero Riviera (northern Adriatic Sea): Relationships with environmental conditions and substrata. Harmful Algae 9, 233-239.

Uchida, T., Matsuyama, Y., Yamaguchi, M., Honjo, T, 1996. The life cycle of Gyrodinium instriatum (Dinophyceae) in culture. Phycol. Res. 44, 119-123.

Vila, M., Garcés, E., Masó, M., 2001. Potentially toxic epiphytic dinoflagellate assemblages on macroalgae in the NW Mediterranean. Aquat. Microb. Ecol. 26, 51-60.

Vila, M., Arín, L., Battocchi, C., Bravo, I., Fraga, S., Penna, A., Reñé, A., Riobó, P., Rodríguez, F., Sala, M.M., Camp, J., De Torres, M., Franco, J.M., 2012. Management of Ostreopsis blooms in recreational waters along the Catalan coast (NW Mediterranean 
Sea): cooperation between a research project and a monitoring program. Cryptogam. Algol. (in press).

Walker, L. M., 1984. Life histories, dispersal and survival in marine, planktonic dinoflagellates. In: Steidinger, K. A., Walker, L. M. (Eds.), Marine Plankton Life Cycle Strategies. CRC press, Florida, USA, pp. 19-34.

Table 1. Isolation data of the Ostreopsis cf. ovata strains.

\begin{tabular}{ccc}
\hline Strain name & Origin & Date of isolation \\
\hline VGO1052 & Llavaneres beach $^{1}$ & August 2009 \\
\hline VGO1066 & Llavaneres beach $^{1}$ & August 2009 \\
\hline VGO1067 & Lopud bay $^{2}$ & October 2009 \\
\hline VGO1068 & Lopud bay $^{2}$ & October 2009 \\
\hline VGO1069 & Lopud bay ${ }^{2}$ & October 2009 \\
\hline VGO1070 & Lopud bay ${ }^{2}$ & October 2009 \\
\hline \multicolumn{3}{c}{${ }^{1}$ Catalonia (Spain) (Fig. 1) } \\
${ }^{2}$ Otok Lopud (Croacia) (Fig.1)
\end{tabular}




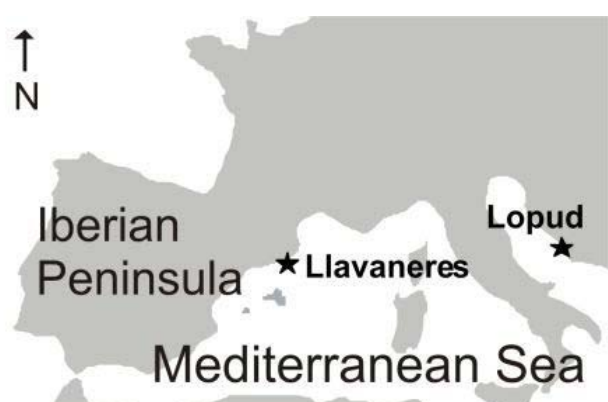

Fig. 1. Map of the northwestern Mediterranean Sea, including the locations where the culture strains were isolated.
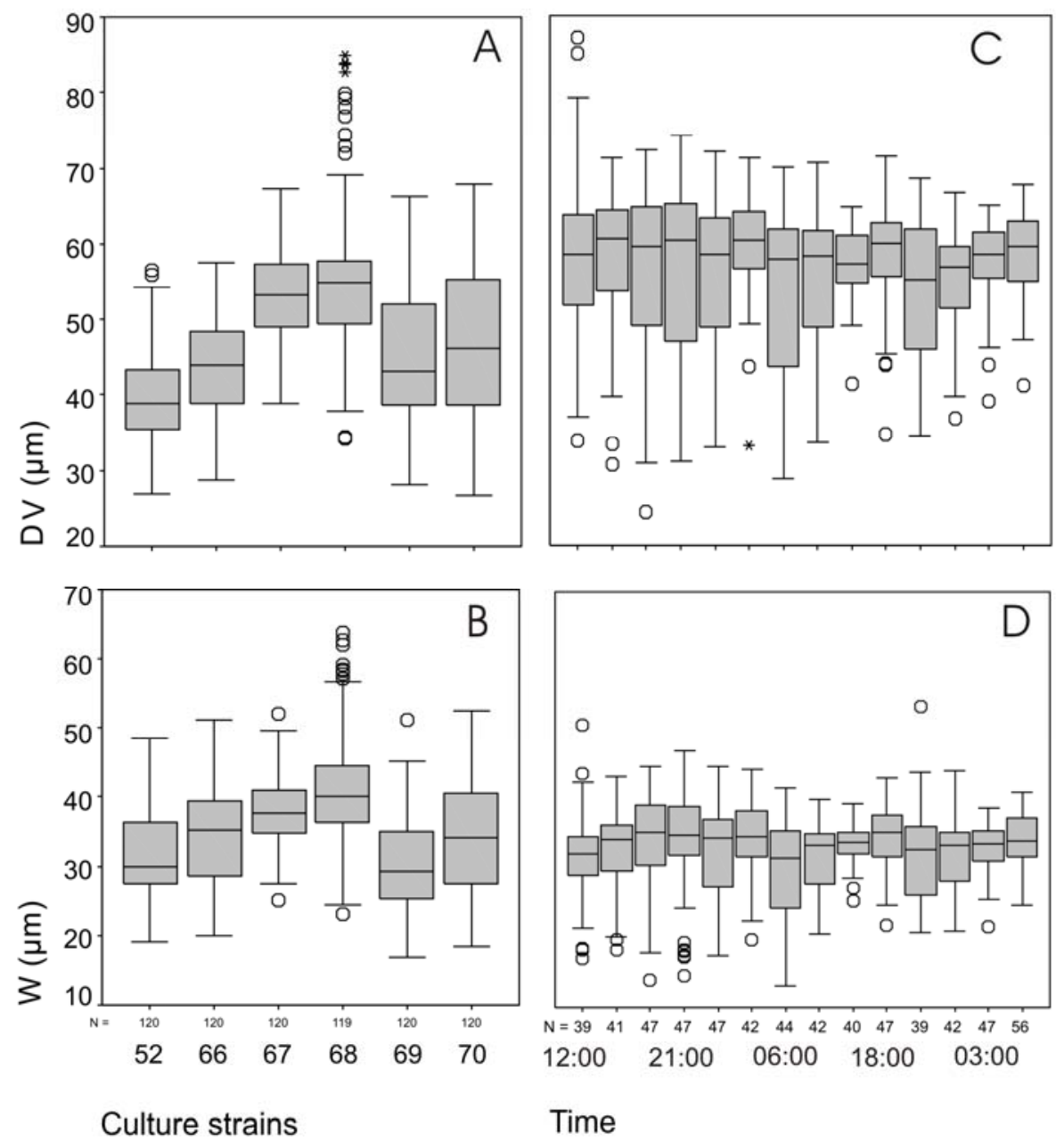

Fig. 2. Box-plot of the dorso-ventral (DV) (A) and transversal (W) (B) diameters of Ostreopsis cf. ovata cells obtained from cultures, as well as DV (C) and (W) (D) diameters of Ostreopsis cf. ovata cells obtained during the 45-h cell-cycle sampling carried out off Llavaneres beach. Strain names have been shortened to the last two digits (see Table 1). 

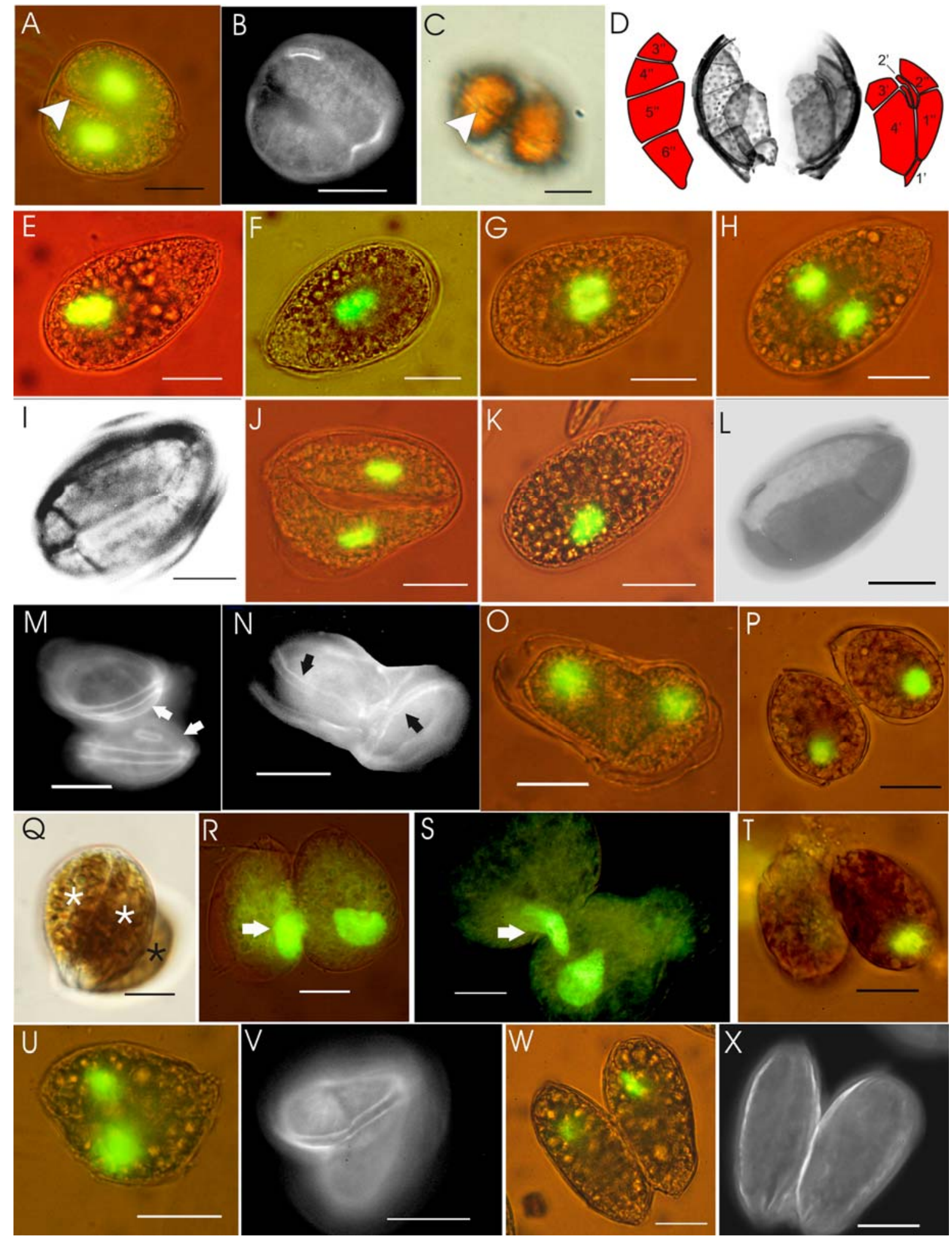

Fig. 3. Asexual and sexual life-cycle stages of Ostreopsis cf. ovata obtained in culture and in the field samples. (A) A culture dividing cell with two nuclei and a partitioned wall (arrow head); (B) calcofluor-stained theca of the same cell as in A; (C) arrowhead points to the cingulum in a cultured dividing cell seen from a dorsal view; (D) the thecal plates and a drawing of the vegetative cell division pattern from cultured cells; (E) stained nucleus of a 
vegetative cell from the field; (F) a centrally located nucleus in a cell from the field, in a stage preceding karyokinesis; $(\mathrm{G})$ karyokinesis in a cell from the field; $(\mathrm{H})$ double-nucleated cells from the field, with slight indications of a partition wall (arrowhead); (I) the same cell stained with Calcofluor; (J) double-nucleated cells from the field undergoing cytokinesis; $(\mathrm{K})$ recently divided cell from the field; (L) the same cell stained with calcofluor; (M) cultured mating gamete pair attached by epithecas (arrows); (N) arrows show the cingula of a cultured mating gamete pair; $(\mathrm{O})$ nuclei from the same cells as in $\mathrm{N}$; (P) the arrow points to the thecal contact in a cultured mating gamete pair; (Q) a dividing cell from a cultured mating pair (white asterisks) and the other non-dividing gamete from the pair (black asterisk); (R) the wall-attached nucleus (arrow) of a cultured mating gamete pair; (S) cultured mating gamete pair in which a nucleus (arrow) is being transferred from one gamete to the other; (T) cultured mating gamete pair with only one nucleated cell; (U) mating gamete pair from the field in an advanced state of fusion; (V) the same cells stained with Calcofluor; (W) mating gamete pair from the field with only surface contact between gametes; $(\mathrm{X})$ the same cells stained with Calcofluor. Scale bars $20 \mu \mathrm{m}$.

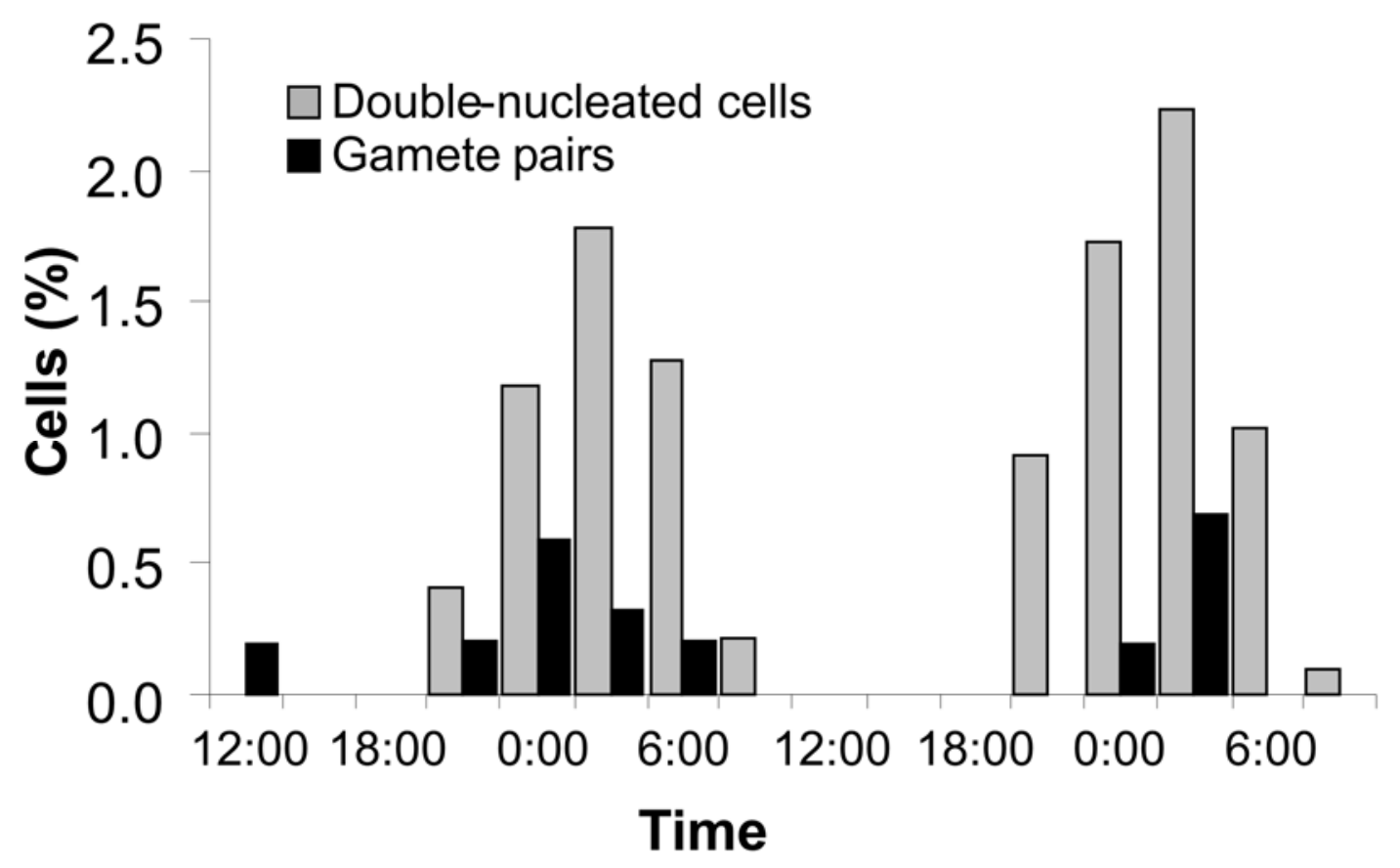

Fig. 4. Pattern of double-nucleated cells (gray) and mating gamete pairs (black) during the 45-h cell-cycle sampling carried out off Llavaneres beach. 


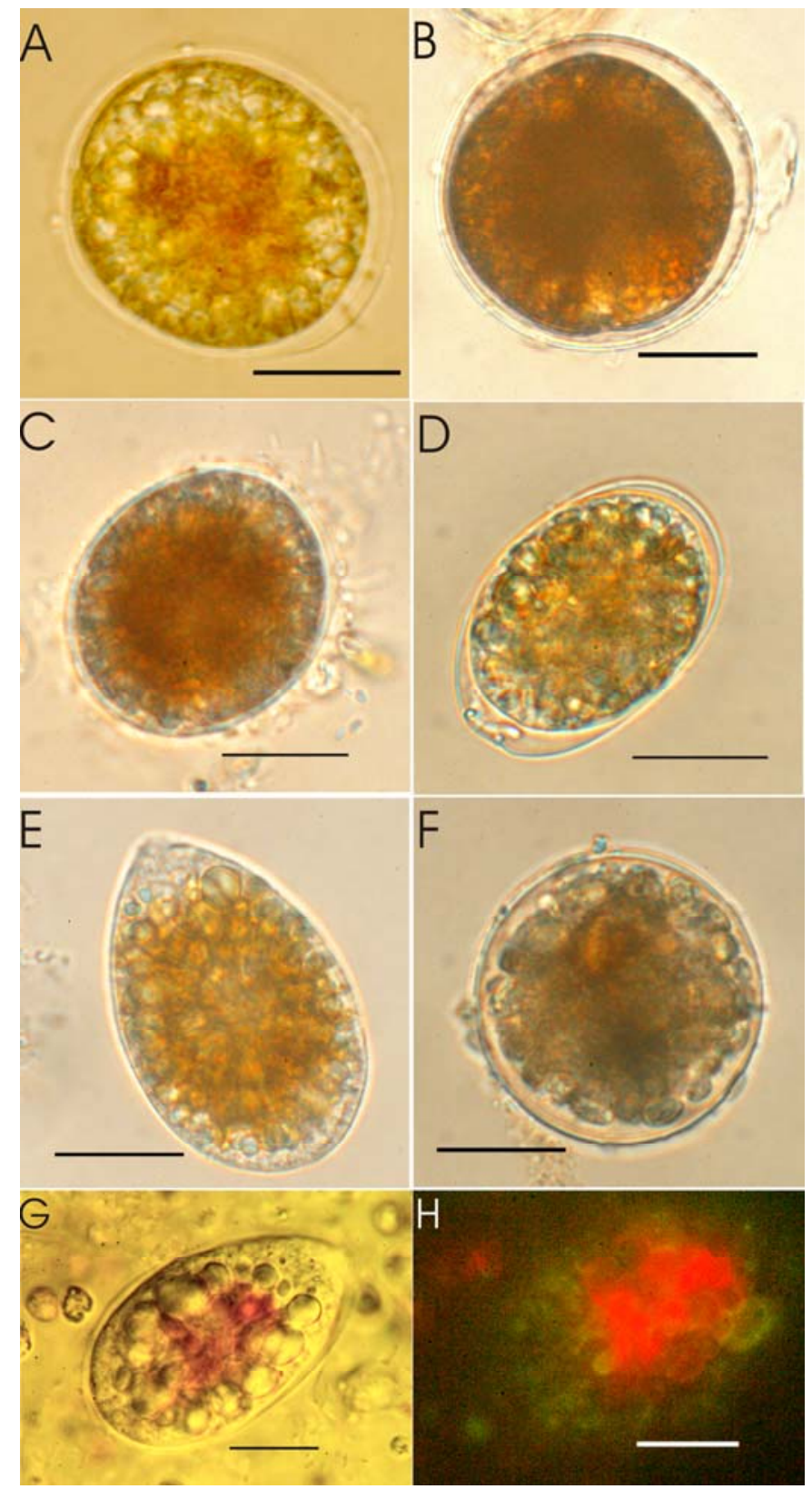

Fig. 5. Cysts of Ostreopsis cf. ovata obtained in culture and in the field samples. Round thinwalled non-germinated (A) and successfully germinated (B) cysts from cultures; (C) round thin-walled cyst obtained from Llavaneres beach; (D) elongated thin-walled cyst from Llavaneres beach; (E) pellicle cyst from Llavaneres beach; (F) a thin-walled cyst, obtained from greater depths off Llavaneres beach that could be attributed to Ostreopsis cf. ovata; (G) cyst embedded in mucus from a laboratory-incubated sample; $(\mathrm{H})$ the same cell exhibits red fluorescence (asterisk) when excited by light at $495 \mathrm{~nm}$. Scale bars $20 \mu \mathrm{m}$. 